\title{
Influence of Nitrogen Sources and Time of Cutting on Yield and Protein Content of Napier (Merker) Grass
}

\author{
George Samuels and Francisco González-Vélez ${ }^{1}$
}

INTRODUCTION

The proper management of forage grasses for cutting or grazing has long been a problem for many farmers in Puerto Rico. During the winter months, with less rainfall, shorter days, and lower temperatures, production of forage diminishes; during the remainder of the year, with greater rainfall, longer days, and higher temperatures, production of forage increases. Farmers with silos can preserve the grasses obtained during the months of high production for use in the winter months when there is a scarcity of forage grass. Farmers without means of preserving their grasses as slage attempt to maintain adequate winter forage by planting an acreage of grasses sufficient to produce enough for the winter months. This practice results in severe management problems of overproduction and deciding on time of cutting and grazing during the spring and summer months. The farmer who tries to maintain the recommended 60-day cutting interval for his grasses finds that many times he must allow his grass to go 90 or more days before cutting. The grass cut or grazed at 90 days is more fibrous and lower in protein content than grass cut or grazed at the recommended 60 day interval.

If this decrease in protein content with the increasing age of the plant could be modified by a nitrogen source which would maintain the protein content at a high level with increasing age, the farmer could find a workable answer to the dilemma of selecting a time of cutting or grazing that would not decrease yield and protein content in forage grasses. This paper presents the results of an experiment carried out to determine the response of $\mathrm{Na}$ pier (Merker) grass (Pennisetum purpureum) to three nitrogen sources as affected by frequency of cutting.

\section{PROCEDURE}

The experiment was carried out at the Gurabo Substation over 2 consecutive years, beginning April 15, 1959. Rainfall was 53.3 and 83.9 inches

${ }^{1}$ Agronomist and former Research Assistant in Agronomy, respectively, Agricultural Experiment Station, University of Puerto Rico, Río Piedras, P.R. The authors wish to thank Mr. E. Reyes Soto, Mr. A. Sierra Bracero, and other members of the Gurabo Substation for their cooperation in obtaining the field data; und Dr. L. Rivera-Brenes, Head of Animal Husbandry Department, for his suggestions during the course of this experiment. 
during the first and second years, respectively, which were 15-inch deviations from the long-time average of about 68 inches. The mean annual temperature is about $76^{\circ} \mathrm{F}$, with seasonal variations of less than $8^{\circ} \mathrm{F}$.

The soil is a Mabi clay, a deep, grayish-brown heavy clay with little or no slope. The surface 8 inches had an initial pH of 5.1.

The treatments used were as follows:

\begin{tabular}{lcl}
\multicolumn{1}{c}{ Nilrogen soutrce } & $\begin{array}{c}\text { Ularsest lecels } \\
(\text { weeks) }\end{array}$ & Liming \\
None & 6 & None \\
Nitroform & 9 & Limed \\
Urea & 12 & \\
Ammonium sulfate & &
\end{tabular}

All combinations of these treatments were tested using a split-plot design, with liming as the main-block effect, harvest levels as the subplots, and nitrogen source as the sub-subplot. The nitrogen sub-subplots were $15 \times 15$ feet surrounded by ditches to prevent fertilizer from washing into adjoining plots.

The upper 8 inches of soil in plots receiving lime to a $\mathrm{pH}$ of about 6.3, using 5 tons of limestone which had a total alkalinity of 97.2 percent expressed as calcium carbonate. Broadcast additions of phosphorus and potassium were made annually at the rate of 100 pounds each of $\mathrm{P}_{2} \mathrm{O}_{5}$ per acre, from 20-percent superphosphate, and $\mathrm{K}_{2} \mathrm{O}$ per acre from $\mathrm{KCl}$. The nitrogen content of the fertilizers used was urea 46, Nitroform 38, and ammonium sulfate 20.5. The nitrogen was applied after each cutting in four to eight equal applications yearly, depending on frequency of cutting. The total nitrogen applied annually per treatment was 520 pounds per acre.

The grass was cut at the prescribed intervals by machete, weighed, and the forage removed from the plots. Samples from each plot at every harvest were analyzed for total nitrogen. The crude-protein content was calculated using the factor 6.25 times $\mathrm{N}$.

\section{RESULTS}

Table 1 shows the yield per acre and percentage protein content of the Napier grass under the various treatments.

\section{YIELD OF GREEN FORAGE PER ACRE}

The annual mean yield of green forage per acre was increased by longer periods between cuttings and by nitrogen applications. The 9-week harvest interval gave significantly more tonnage of forage than did the 6-week interval, but the increase from the 12-week harvest interval was not significantly better in tonnage yields than the 9-week. This applied to all nitrogen sources, and the average, except for urea, where the 12-week cutting was significantly higher in yields than the 9-week. Vicente-Chand- 
ler et al. $(3)^{2}$ found that the yield of green forage per acre from Napier grass increased markedly with greater length of harvest intervals from 40 to 60 , and to 90 days.

There was a significant increase in forage tonnage for all of the nitrogen sources used over the no-nitrogen treatment at all of the harvest intervals used (table 1).

Of the three nitrogen sources used, ammonium sulfate gave the highest yields of green forage per acre for the average of the three harvest intervals. Urea was second in producing yield increases, the figure being signifi-

TABLE 1.-The effects of nitrogen sources and intervals of cutting on yields of green forage per acre, and percenlage prolein in Napier (Merker) grass

\begin{tabular}{|c|c|c|c|c|c|c|c|c|}
\hline \multirow{2}{*}{ Nitrogen source } & \multicolumn{4}{|c|}{$\begin{array}{l}\text { Annual mean yields per acre of } \\
\text { green forage for cutting time of }\end{array}$} & \multicolumn{4}{|c|}{$\begin{array}{l}\text { Annual mean yield of protein } \\
\text { for cutting time of }-\end{array}$} \\
\hline & 6 weeks & 9 weeks & 12 weeks & Average & 6 weeks & 9 weeks & $\mid 12$ weeks & Average \\
\hline & Tons & Tons & Tons & Tons & Percent & Percent & Percent & Percent \\
\hline None & 21.7 & 37.6 & 37.1 & 32.1 & 8.53 & 6.42 & 5.08 & 6.68 \\
\hline Nitroform & 37.9 & 52.5 & 55.1 & 48.5 & 10.77 & 7.03 & 5.30 & 7.70 \\
\hline Urea & 46.0 & 55.0 & 67.4 & 56.1 & 11.56 & 7.53 & 6.06 & 8.38 \\
\hline Ammonium sulfate & 46.2 & 67.0 & 70.2 & 61.1 & 12.88 & 8.99 & 6.97 & 9.61 \\
\hline Average $^{1}$ & 38.0 & 53.0 & 57.0 & 49.5 & 10.94 & 7.49 & 5.85 & 8.08 \\
\hline $\begin{array}{l}\text { Least significant difierence } \\
\text { needed between treatments } \\
\text { at: }\end{array}$ & & & & & & & & \\
\hline 5-percent level & 7.41 & 7.41 & 7.41 & 4.27 & 0.46 & 0.46 & 0.46 & 0.27 \\
\hline 1-percent level & 9.83 & 9.83 & 9.83 & 5.69 & .62 & .62 & .62 & .36 \\
\hline
\end{tabular}

1 Least significant difference needed for comparison between the averages of the weeks of cutting treatments for yields of green forage at 5-percent level 7.80, 1percent level 10.85 , and percentage of protein at 5-percent level $0.35,1$-percent level 0.49 .

cantly lower than for ammonium sulfate, with Nitroform last. Ammonium sulfate was superior to urea at the 9-week cutting interval, but not at 6or 12-week intervals. Vicente-Chandler and Figarella (2) reported higher yields of dry Napier grass, forage when cut every 60 days, from ammonium sulfate as compared with urea; this difference was significant for pounds of crude protein per acre, but not for pounds of dry forage.

\section{PROTEIN CONTENT}

The percentage protein in the Napier grass was greatly influence by nitrogen source and by harvesting interval (table 1). There was a decrease

2 Italic numbers in parentheses refer to Literature Cited, p. 211. 
in the protein content of the Napier grass as the length of the harvest interval increased from 6 to 12 weeks. The decrease was not quite as rapid from the 9- to 12-week cutting intervals as it was for the 6- to 9-week intervals. Vicente-Chandler, Silva, and Figarella found this decrease in protein content with increased harvest intervals for Napier grass (3).

The nitrogen source used had a great influence on the protein content of the Napier grass. The highest protein content was achieved with ammonium sulfate. The urea-treated grass was second highest in protein content; however, the ammonium sulfate-treated grass always had a sig-

TABLE 2.-The yields of green forage per acre and of prolein under various nitrogen sources, with and withoul liming Napier (Merker) grass

\begin{tabular}{|c|c|c|c|c|}
\hline \multirow{2}{*}{ Nitrogen source } & \multicolumn{2}{|c|}{$\begin{array}{l}\text { Annual yield of green forage } \\
\text { per acre }\end{array}$} & \multicolumn{2}{|c|}{$\begin{array}{l}\text { Protein content of } \\
\text { forage }\end{array}$} \\
\hline & Unlimed & Limed & Unlimed & Limed \\
\hline $\begin{array}{l}\text { None } \\
\text { Nitroform } \\
\text { Urea } \\
\text { Ammonium sulfate }\end{array}$ & $\begin{array}{c}\text { Tons } \\
30.5 \\
46.9 \\
55.5 \\
60.8\end{array}$ & $\begin{array}{c}\text { Tons } \\
33.7 \\
50.1 \\
56.8 \\
61.5\end{array}$ & $\begin{array}{c}\text { Percent } \\
6.79 \\
7.77 \\
8.49 \\
9.83\end{array}$ & $\begin{array}{c}\text { Percent } \\
6.51 \\
7.65 \\
8.25 \\
9.20\end{array}$ \\
\hline Average ${ }^{1}$ & 48.4 & 50.5 & 8.22 & 7.90 \\
\hline $\begin{array}{c}\text { Least significant difference be- } \\
\text { tween treatments at: } \\
5 \text {-percent level } \\
1 \text {-percent level }\end{array}$ & $\begin{array}{r}9.6 \\
14.6\end{array}$ & $\begin{array}{l}6.2 \\
9.4\end{array}$ & $\begin{array}{r}0.48 \\
.72\end{array}$ & $\begin{array}{r}0.26 \\
.40\end{array}$ \\
\hline
\end{tabular}

1 The differences in yields of green forage and percentage protein between the averages for limed and unlimed treatments are not significant.

nificantly higher protein content at all three harvest intervals. VicenteChandler and Figarella also found that ammonium sulfate gave a higher protein content than did urea used on Napier grass (2).

Nitroform was inferior to ammonium sulfate and urea as a nitrogen source, judged by the percentage protein content of the Napier grass. It exceeded only the no-nitrogen treatment in increasing the protein percentage.

None of the nitrogen sources used had the ability to maintain protein at high levels in the grass when the harvest interval increased. The factor of the length of harvest interval was so strong that, when it was increased from 6 to 12 weeks, the protein content of the grasses decreased almost half, 
despite the nitrogen source used. Thus the farmer who has increased his grass acreage to compensate for lower yields in the winter cannot hope to produce a higher protein grass by use of special nitrogen sources, if his harvest interval increases.

It appears that ammonium sulfate is better than urea or Nitroform in giving a higher percentage protein content, but it cannot maintain the Napier grass at or about the same protein level when the harvest spacing is increased from 6 - to 9 -week intervals.

TABLE 3.-The $p H$ values of a Mabi clay soil 1 year afler lime was applied, when planted to Napier (Merker) grass and receiving various nitrogen sources

\begin{tabular}{l|c|c|c}
\hline \multirow{2}{*}{ Nitrogen source } & Soil depth & \multicolumn{2}{|c}{ Soil pH values for } \\
\cline { 2 - 3 } & & Unlimed soil & Limed soil \\
\hline \multirow{3}{*}{ None } & Inches & & \\
& $0-6$ & 4.9 & 5.4 \\
& $6-12$ & 5.5 & 5.4 \\
Nitroform & $12-18$ & 5.7 & 6.1 \\
& $0-6$ & & 6.3 \\
& $6-12$ & 5.9 & 5.6 \\
Ureu & $12-18$ & 6.1 & 6.3 \\
& $0-6$ & 4.8 & 6.2 \\
& $0-12$ & 5.5 & 5.9 \\
Ammonium sulfate & $12-18$ & 6.1 & 6.1 \\
& $0-6$ & 4.5 & 5.8 \\
& $12-18$ & 5.1 & 5.5 \\
& & 6.1 & 5.9 \\
\hline
\end{tabular}

\section{LIMING}

The application of lime did not significantly change the annual yield of green forage per acre, nor its protein content, as compared with no liming (table 2). The $\mathrm{pH}$ values of the soil were higher at the 0-to-6-inch soil depth when limed (table 3). The 6-to-12- and 12-to-18-inch depths had about equal soil $\mathrm{pH}$ values whether limed or unlimed. The soil $\mathrm{pH}$ where no lime was applied decreased at the 0-to-6 and 6-to-12-inch depths when ammonium sulfate was used. The lowering of soil $\mathrm{pH}$ from the use of ammonium sulfate has been demonstrated by Samuels and GonzálezVélez (1), and Vicente-Chandler, Silva, and Figarella (2). 


\section{SUMMARY}

Ammonium sulfate, urea, and Nitroform were evaluated as nitrogen sources for Napier (Merker) grass (Pennisetum purpureum), as influenced by liming and harvesting interval. The results indicated that:

1. The annual mean yield of green grass per acre was increased by longer harvest or cutting intervals. The 9 -week harvest interval gave significantly more tonnage of forage than did the 6-week interval, but the 12-week interval was not significantly better than the 9-week.

2. There was a significant increase in forage tonnage attributable to nitrogen sources used, over the no-nitrogen treatment at all harvest intervals.

3. Ammonium sulfate gave the highest yields of green forage and percentages of protein for the average of the three harvest intervals.

4. The protein content of Napier grass decreased with increasing harvest intervals, and none of the nitrogen sources used prevented or modified this decrease.

5. Liming did not significantly increase yields of green forage per acre or percentages of protein.

\section{RESUMEN}

Se evaluaron tres fuentes de nitrógeno, a saber, sulfato amónico, urea y nitroform en el cultivo de la yerba Napier (Merker) (Pennisetum purpureum), a la luz de dos factores: la aplicación de cal al terreno y la variación en los intervalos entre cosechas. Los resultados fueron los siguientes:

1. El promedio anual de rendimiento de yerba verde por acre aumentó cuando se extendieron los intervalos entre cosechas. El corte a intervalos de 9 semanas rindió un tonelaje mayor de yerba que el que se hizo a las 6 semanas, pero el aumento del que se hizo a las 12 semanas no fue, estadisticamente mejor, que el que se logró a las 9 semanas.

2. El tonelaje de yerba aumentó de manera significativa estadísticamente en todos los cortes hechos a distintos intervalos, sin importar la fuente de nitrógeno utilizada, cuando se comparó con el rendimiento de las parcelas que no fueron abonadas con nitrógeno.

3. El sulfato amónico produjo los rendimientos mayores de yerba verde y los porcentajes más altos de proteína a base del promedio de rendimiento de los tres cortes a diferentes intervalos.

4. El contenido de proteína de la yerba Napier disminuyó según se extendieron los intervalos entre cortes sin que ninguna de las fuentes de nitrógeno usadas surtiera efecto alguno para evitar esta reducción del contenido de proteína.

5. La aplicación de cal no tuvo efecto significativo, estadísticamente, sobre el aumento en el rendimiento por acre de yerba verde o sobre su porcentaje de proteína. 


\section{LITERATURE CITED}

1. Samuels, G., and González-Vélez, F., The influence of ammonium sulfate fertilization on the pH of sugarcane soils, J. Agr. Univ. P.R. 46 (4) 297-306, 1962.

2. Vicente-Chandler, J., and Figarella, J., Effects of five nitrogen sources on yield and composition of Napier grass, J. Agr. Univ. P.R. 46 (2) 102-6, 1962.

3. Vicente-Chandler, Silva, S., and Figarella, J., Effects of nitrogen fertilization and frequency of cutting on the yield and composition of Napier grass in Puerto Rico, J. Agr. Univ. P.R. 43 (4) 215-27, 1959. 